\title{
METODE BELAJAR AKTIF DAN MODEL PENGAJARAN TERARAH UNTUK MENINGKATKAN PRESTASI BELAJAR IPS DI SDN 04 KALIMAS
}

\author{
Djaman \\ Sekolah Dasar Negeri 04 Kalimas \\ Email:djamansdn04kalimas@gmail.com
}

\begin{abstract}
Abstrak
Ada kecenderungan dalam dunia pendidikan dewasa ini untuk kembali pada pemikiran bahwa anak akan belajar lebih baik jika lingkungan diciptakan secara alamiah. Belajar akan lebih bermakna jika anak "mengalami" sendiri apa yang dipelajarinya, bukan 'mengetahui'-nya. Pembelajaran yang berorientasi target penguasaan materi terbukti berhasil dalam kompetisi 'mengingat' jangka pendek, tetapi gagal dalam membekali anak memecahkan persoalan dalam kehidupan jangkan panjang. Penelitian ini menggunakan penelitian tindakan (action research) sebanyak tiga putaran. Setian putaran terdiri dari empat tahap yaitu: rancangan, kegiatan dan pengamatan, refleksi, dan refisi. Sasaran penelitian ini adalh siswa kelas V SDN 07 Semanai. Data yang diperoleh berupa hasil tes formatif, lembar observasi kegiatan belajar mengajar. Dari hasil analis didapatkan bahwa prestasi belajar siswa mengalami peningkatan dari siklus I sampai siklus III yaitu, siklus I $(65,63 \%)$, siklus II $(75,00 \%)$, siklus III $(87,50 \%)$. Simpulan dari penelitian ini adalah metode belajar aktif model pengajaran terarah dapat berpengaruh positif terhadap motivasi belajar Siswa SDN 07 Semanai, serta model pembelajaran ini dapat digunakan sebagai salah satu alternatif pembelajaran IPS.
\end{abstract}

\section{Kata Kunci: Penerapan, Metode Belajar Aktif, Model Pengajaran Terarah}

\section{PENDAHULUAN}

Dalam kegiatan belajar mengajar tidak semua anak didik mampu berkonsentrasi dalam waktu yang relatif lama. Daya serap anak didik terhadap bahan yang diberikan juga bermacam-macam, ada yang cepat, ada yang sedang, dan ada yang lambat. Faktor intelegensi mempengaruhi daya serap anak didik terhadap bahan pelajaran yang diberikan oleh guru. Cepat lambatnya penerimaan anak didik terhadap bahan pelajaran yang diberikan menghendaki pemberian waktu yang bervariasi, sehingga penguasaan penuh dapat tercapai.

Terhadap perbedaan daya serap anak didik sebagaimana tersebut di atas, memerlukan strategi pengajaran yang tepat. Metodelah salah satu jawabannya. Untuk sekelompok anak didik boleh jadi mereka mudah menyerap bahan pelajaran bila guru menggunakan metode tanya jawab, tetapi untuk sekelompok anak didik yang lain mereka lebih mudah menyerap bahan pelajaran bila guru menggunakan metode demonstrasi atau eksperimen.

Karena itu dalam kegiatan belajar mengajar, menurut Roestiyah, N.K. (1989: 1), guru harus memiliki strategi agar anak didik dapat belajar secara efektif dan efisien, mengena pada tujuan yang diharapkan. Salah satu langkah untuk memiliki strategi itu adalah harus menguasai teknik-teknik penyajian atau biasanya disebut metode mengajar. Dengan demikian, metode mengajar adalah stategi pengajaran sebagai alat untuk mencapai tujuan yang diharapkan.

Apa yang menjadikan belajar aktif? Agar belajar menjadi aktif siswa harus mengerjakan banyak sekali tugas. Mereka harus menggunakan otak, mengkaji gagasan, memecahkan masalah, dan menerapkan apa yang mereka pelajari. Belajar aktif harus 
gesit, menyenangkan, bersemangat dan penuh gairah. Siswa bahkan sering meninggalkan tempat duduk mereka, bergerak leluasa dan berfikir keras (moving about dan thinking aloud)

Dengan menyadari gejala-gejala atau kenyataan tersebut diatas, maka diadakan penelitian dengan judul Pengaruh Metode Belajar Aktif Model Pengajaran Terarah Dalam Meningkatkan Prestasi Dan Pemahaman Pelajaran IPS Pada Siswa Kelas V SDN 04 Kalimas.

Pemecahan masalah yang diterapkan dalam penelitian ini adalah dengan menerapkan metode belajar aktif model pengajaran terarah, dengan menerapkan metode belajar ini diharapkan prestasi belajar siswa dapat meningkat.

Karena keterbatasan waktu, maka diperlukan pembatasan masalah yang meliputi: (1) Penelitian ini hanya dikenakan pada siswa kelas V SDN 04 Kalimas Tahun Pelajaran 2018/2019. (2) Penelitian ini dilaksanakan pada semester ganjil bulan September tahun pelajaran 2018/2019. (3) Materi yang disampaikan adalah Makna peninggalan-peninggalan sejarah yang berskala nasional dan masa Hindu-Budha, dan Islam di Indonesia.

Sesuai dengan permasalahan di atas, penelitian ini bertujuan untuk: (1) Mengetahui peningkatan prestasi belajar IPS setelah diterapkannya metode belajar aktif model pengajaran terarah pada siswa Kelas V SDN 04 Kalimas Tahun Pelajaran 2018/2019. (2) Mengetahui pengaruh motivasi belajar IPS setelah diterapkan metode belajar aktif model pengajaran terarah pada siswa Kelas V SDN 04 Kalimas Tahun Pelajaran 2018/2019.

Adapun maksud penulis mengadakan penelitian ini diharapkan dapat berguna sebagai: (1) Menambah pengetahuan dan wawasan penulis tentang peranan guru IPS dalam meningkatkan pemahaman siswa belajar IPS. (2) Sumbangan pemikiran bagi guru IPS dalam mengajar dan meningkatkan pemahaman siswa belajar IPS.

Motif adalah daya dalam diri seseorang yang mendorongnya untuk melakukan sesuatu, atau keadaan seseorang atau organisme yang menyebabkan kesiapannya untuk memulai serangkaian tingkah laku atau perbuatan. Sedangkan motivasi adalah suatu proses untuk menggiatkan motif-motif menjadi perbuatan atau tingkah laku untuk memenuhi kebutuhan dan mencapai tujuan, atau keadaan dan kesiapan dalam diri individu yang mendorong tingkah lakunya untuk berbuat sesuatu dalam mencapai tujuan tertentu (Usman, 2000:28).

Menurut Winata (dalam Erriniati, 1997:105) ada beberapa strategi dalam mengajar untuk membangun motivasi intrinsik. Strategi tersebut adalah sebagai berikut: (1) Mengaitkan tujuan belajar dengan tujuan siswa. (2) Memberikan kebebasan dalam memperluas materi pelajaran sebatas yang pokok. (3) Memberikan banyak waktu ekstra bagi siswa untuk mengerjakan tugas dan memanfaatkan sumber belajar di sekolah. (4) Sesekali memberikan penghargaan pada siswa atas pekerjaannya. (5) Meminta siswa untuk menjelaskan hasil pekerjaannya.

Dari uraian diatas dapat disimpulkan bahwa motivasi instrinsik adalah motivasi yang timbul dari dalam individu yang berfungsinya tidak perlu dirangsang dari luar. Seseorang yang memiliki motivasi intrinsik dalam dirinya maka secara sadar akan melakukan suatu kegiatan yang tidak memerlukan motivasi dari luar dirinya.

Jenis motivasi ini timbul sebagai akibat pengaruh dari luar individu, apakah karena adanya ajakan, suruhan, atau paksaan dari orang lain sehingga dengan kondisi yang demikian akhirnya ia mau melakukan sesuatu atau belajar. Misalnya seseorang mau belajar karena ia disuruh oleh orang tuanya agar mendapat peringkat pertama dikelasnya (Usman, 2000:29).

Sedangkan menurut Djamarah (2002:117), motivasi ekstrinsik adalah kebalikan dari motivasi intrinsik. Motivasi ekstrinsik adalah motif-motif yang aktif dan berfungsi karena adanya perangsang dari luar.

Dalam teknik ini, guru mengajukan satu atau beberapa pertanyaan untuk melacak pengetahuan siswa atau mendapatkan hipotesis atau simpulan mereka dan kemudian memilah-milahnya menjadi sejumlah 
kategori. Metode pengajaran terarah merupakan selingan yang mengasyikan di sela-sela cara pengajaran biasa. Cara ini memungkinkan guru untuk mengetahui apa yang telah diketahui dan dipahami oleh siswa sebelu memaparkan apa yang guru ajarkan. Metode ini sangat berguna dalam mengajarkan konsep-konsep abstrak.

Ajukan pertanyaan atau serangkaian pertanyaan yang menjajaki pemikiran siswa dan pengetahuan yang mereka miliki. Gunakan pertanyaan yang memiliki beberapa kemungkinan jawaban, semisal "Bagaimana kamu menjelaskan seberapa cerdanya seseorang?" (2) Berikan waktu yang cukup kepada bagi siswa dalam pasangan atau kelompok untuk membahas jawaban mereka. (3) Perintahkan siswa untuk kembali ke tempat masing-masing dan catatlah pendapat mereka. Jika memungkinkan, seleksi jawaban mereka menjadi beberapa kategori terpisah yang terkait dengan kategori atau konsep yang berbeda semisal "kemampuan membuat mesin" pada kategori kecerdasan kinestetikatubuh. (4) Sajikan poin-poin pembelajaran utama yang ingin anda ajarkan. Perintahkan siswa untuk menjelaskan kesesuaian jawaban mereka dengan poin-poin ini. Catatlah gagasan yang memberi informasi tambahan bagi poin pembelajaran.

Jangan memilah-milah jawaban siswa menjadi daftar yang terpisah. Sebagai gantinya, buatlah satu daftar panjang dan perintahkan mereka untuk mengkategorikan gagasan mereka terlebih dahulu sebelum guru membandingkannya dengan konsep yang ada di pikiran anda.

Mulailah pelajaran dengan tanpa kategori yang sudah ada di benak guru. Cermati bagaimana siswa dan guru secara bersama-sama bisa memilah-milah gagasan mereka menjadi kategori yang berguna.

\section{METODE PENELITIAN}

Penelitian ini dirancang untuk dilakukan dalam tiga siklus. Menurut pengertiannya penelitian tindakan adalah penelitian tentang hal-hal yang terjadi dimasyarakat atau sekolompok sasaran, dan hasilnya langsung dapat dikenakan pada masyarakat yang bersangkutan (Arikunto, 2002:82). Ciri atau karakteristik utama dalam penelitian tindakan adalah adanya partisipasi dan kolaborasi antara peneliti dengan anggota kelompok sasaran. Penelitian tidakan adalah satu strategi pemecahan masalah yang memanfaatkan tindakan nyata dalam bentuk proses pengembangan invovatif yang dicoba sambil jalan dalam mendeteksi dan memecahkan masalah. Dalam prosesnya pihak-pihak yang terlibat dalam kegiatan tersebut dapat saling mendukung satu sama lain.

Sedangkan tujuan penelitian tindakan harus memenuhi beberapa prinsip sebagai berikut: (1) Permasalahan atau topik yang dipilih harus memenuhi kriteria, yaitu benarbenar nyata dan penting, menarik perhatian dan mampu ditangani serta dalam jangkauan kewenangan peneliti untuk melakukan perubahan. (2) Kegiatan penelitian, baik intervensi maupun pengamatan yang dilakukan tidak boleh sampai mengganggu atau menghambat kegiatan utama. (3) Jenis intervensi yang dicobakan harus efektif dan efisien, artinya terpilih dengan tepat sasaran dan tidak memboroskan waktu, dana dan tenaga. (4) Metodologi yang digunakan harus jelas, rinci, dan terbuka, setiap langkah dari tindakan dirumuskan dengan tegas sehingga orang yang berminat terhadap penelitian tersebut dapat mengecek setiap hipotesis dan pembuktiannya. (5) Kegiatan penelitian diharapkan dapat merupakan proses kegiatan yang berkelanjutan (on-going), mengingat bahwa pengembangan dan perbaikan terhadap kualitas tindakan memang tidak dapat berhenti tetapi menjadi tantangan sepanjang waktu. (Arinkunto, 2002:82-83).

Tempat penelitian adalah tempat yang digunakan dalam melakukan penelitian untuk memperoleh data yang diinginkan. Penelitian ini bertempat di SDN 04 Kalimas Tahun Pelajaran 2018/2019.

Waktu penelitian adalah waktu berlangsungnya penelitian atau saat penelitian ini dilangsungkan. Penelitian ini dilaksanakan pada bulan Agustus sampai dengan November semester ganjil tahun pelajaran 2018/2019. 
Subyek penelitian adalah siswa-siswi Kelas V SDN 04 Kalimas Tahun Pelajaran 2018/2019 pada pokok bahasan Makna peninggalan-peninggalan sejarah yang berskala nasional dan masa Hindu-Budha, dan Islam di Indonesia.

Penelitian ini dilaksanakan melalui 5 tahap, yaitu, (1) tahap perencanaan, (2) tahap persiapan, dan (3) tahap pelaksanaan, (4) tahap pengolahan data, dan (5) penyusunan Laporan. Tahap-tahap tersebut dapat dirinci seperti sebagai berikut.

Pada tahap perencanaan ini kegiatan yang dilakukan meliputi, (1) observasi di sekolah, (2) penyusunan proposal penelitian.

Pada tahap persiapan ini meliputi, (1) pembuatan RP (rencana pembelajaran), (2) pembuatan LO (lembar observsi) minat perhatian dan partisipasi siswa, (3) pembuatan soal tes formatif, (4) pembuatan rambu-rambu penilaian, (5) uji coba instrumen, dan (6) seleksi dan revisi instrumen.

Tahap pelaksanaan merupakan kegiatan yang banyak berhubungan dengan lapangan dan pengolahan hasil penelitian. Tahap pelaksanaan meliputi, (1) tahap pengumpulan data dan (2) tahap pengolahan data.

Pada tahap ini meliputi, (1) penyusunan laporan penelitian dan (2) penggandaan laporan. Pada penelitian ini menggunakan teknik analisis deskriptif kualitatif, yaitu suatu metode penelitian yang bersifat menggambarkan kenyataan atau fakta sesuai dengan data yang diperoleh dengan tujuan untuk mengetahui prestasi belajar yang dicapai siswa juga untuk memperoleh respon siswa terhadap kegiatan pembelajaran serta aktivitas siswa selama proses pembelajaran.

Untuk mengalinasis tingkat keberhasilan atau persentase keberhasilan siswa setelah proses belajar mengajar setiap putarannya dilakukan dengan cara memberikan evaluasi berupa soal tes tertulis pada setiap akhir putaran.

\section{HASIL DAN PEMBAHASAN}

Data penelitian yang diperoleh adalah data observasi berupa pengamatan pengelolaan belajar aktif dan pengamatan aktivitas siswa dan guru pada akhir pembelajaran, dan data tes formatif siswa pada setiap siklus.

Data lembar observasi diambil dari dua pengamatan yaitu data pengamatan pengelolaan pembelajaran metode pengajaran terarah yang digunakan untuk mengetahui pengaruh penerapan metode pengajaran terarah dalam meningkatkan prestasi

Data tes formatif untuk mengetahui peningkatan prestasi belajar siswa setelah diterapkan belajar aktif. Pada tahap ini peneliti mempersiapkan perangkat pembelajaran yang terdiri dari rencana pelajaran 1, LKS 1 , soal tes formatif 1 dan alat-alat pengajaran yang mendukung.

Pelaksanaan kegiatan belajar mengajar untuk siklus I dilaksanakan pada tanggal 1 September 2018 di Kelas V dengan jumlah siswa 32 siswa. Dalam hal ini peneliti bertindak sebagai pengamat dengan dibantu oleh kepala sekolah SDN 04 Kalimas, sedangkan yang bertindak sebagai pengajar adalah guru kelas SDN 04 Kalimas. Adapun proses belajar mengajar mengacu pada rencana pelajaran yang telah dipersiapkan. Pengamatan (observasi) dilaksanakan bersamaan dengan pelaksaaan belajar mengajar.

Pada akhir proses belajar mengajar siswa diberi tes formatif I dengan tujuan untuk mengetahui tingkat keberhasilan siswa dalam proses belajar mengajar yang telah dilakukan. Adapun data hasil penelitian pada siklus I. Berdasarkan tabel di atas aspek-aspek yang mendapatkan kriteria kurang baik adalah memotivasi siswa, menyampaikan tujuan pembelajaran, pengelolaan waktu, dan siswa antusias. Keempat aspek yang mendapat penilaian kurang baik di atas, merupakan suatu kelemahan yang terjadi pada siklus I. Dan akan dijadikan bahan kajian untuk refleksi dan revisi yang akan dilakukan pada siklus II.

Aktivitas guru yang paling dominan pada siklus I adalah membimbing dan mengamati siswa dalam menemukan konsep yaitu 21,7\%. Aktivitas lain yang persentasenya cukup besar adalah memberi umpan balik/evaluasi/tanya jawab dan menjelaskan materi yang sulit yaitu masing- 
masing sebesar $18,3 \%$ dan $13,3 \%$. Sedangkan aktivitas siswa yang paling dominan adalah mengerjakan/ memper- hatikan penjelasan guru yaitu 22,5\%. Aktivitas lain yang persentasenya cukup besar adalah bekerja dengan sesama anggota kelompok, diskusi antar siswa/antara siswa dengan guru, dan membaca buku yaitu masing-masing $18,7 \%$ 14,4 dan $11,5 \%$.

Pada siklus I, secara garis besar kegiatan belajar mengajar dengan merapkan metode pengajaran terarah sudah dilaksanakan dengan baik, walaupun peran guru masih cukup dominan untuk memberikan penjelasan dan arahan karena model tersebut masih dirasakan baru oleh siswa.

Berikutnya adalah rekapitulasi hasil tes formatif siswa dapat dijelaskan bahwa dengan menerapkan metode belajar aktif model pengajaran terarah diperoleh nilai rata-rata prestasi belajar siswa adalah 68,75 dan ketuntasan belajar mencapai $65,63 \%$ atau ada 21 siswa dari 32 siswa sudah tuntas belajar. Hasil tersebut menunjukkan bahwa pada siklus pertama secara klasikal siswa belum tuntas belajar, karena siswa yang memperoleh nilai $\geq 65$ hanya sebesar $65,63 \%$ lebih kecil dari persentase ketuntasan yang dikehendaki yaitu sebesar $85 \%$. Hal ini disebabkan karena siswa masih merasa baru dan belum mengerti apa yang dimaksudkan dan digunakan guru dengan menerapkan metode belajar aktif model pengajaran terarah.

Dalam pelaksanaan kegiatan belajar mengajar diperoleh informasi dari hasil pengamatan sebagai berikut: (1) Guru kurang baik dalam memotivasi siswa dan dalam menyampaikan tujuan pembelajaran. (2) Guru kurang baik dalam pengelolaan waktu (3) Siswa kurang begitu antusias selama pembelajaran berlangsung.

Pelaksanaan kegiatan belajar mengajar pada siklus I ini masih terdapat kekurangan, sehingga perlu adanya refisi untuk dilakukan pada siklus berikutnya. (1) Guru perlu lebih terampil dalam memotivasi siswa dan lebih jelas dalam menyampaikan tujuan pembelajaran. Dimana siswa diajak untuk terlibat langsung dalam setiap kegiatan yang akan dilakukan. (2) Guru perlu mendistribusikan waktu secara baik dengan menambahkan informasi-informasi yang dirasa perlu dan memberi catatan. (3) Guru harus lebih terampil dan bersemangat dalam memotivasi siswa sehingga siswa bisa lebih antusias.

\section{Siklus II}

Pada tahap ini peneliti mempersiapkan perangkat pembelajaran yang terdiri dari rencana pelajaran 2 , LKS, 2, soal tes formatif 2 dan alat-alat pengajaran yang mendukung.

Pelaksanaan kegiatan belajar mengajar untuk siklus II dilaksanakan pada tanggal 8 Oktober 2018 di Kelas V dengan jumlah siswa 32 siswa. Dalam hal ini peneliti bertindak sebagai pengamat dengan dibantu oleh kepala sekolah SDN 04 Kalimas, sedangkan yang bertindak sebagai pengajar adalah guru kelas SDN 04 Kalimas. Adapun proses belajar mengajar mengacu pada rencana pelajaran dengan memperhatikan revisi pada siklus I, sehingga kesalahan atau kekurangan pada siklus I tidak terulang lagi pada siklus II. Pengamatan (observasi) dilaksanakan bersamaan dengan pelaksanaan belajar mengajar.

Pada akhir proses belajar mengajar siswa diberi tes formatif II dengan tujuan untuk mengetahui tingkat keberhasilan siswa dalam proses belajar mengajar yang telah dilakukan. Instrumen yang digunakan adalah tes formatif II. Adapun data hasil penelitian pada siklus II.

Dari tabel diatas, tampak aspek-aspek yang diamati pada kegiatan belajar mengajar (siklus II) yang dilaksanakan oleh guru dengan menerapkan metode pengajaran terarah mendapatkan penilaian yang cukup baik dari pengamat. Maksudnya dari seluruh penilaian tidak terdapat nilai kurang. Namum demikian penilaian tersebut belum merupakan hasil yang optimal, untuk itu ada beberapa aspek yang perlu mendapatkan perhatian untuk penyempurnaan penerapan pembelajaran selanjutnya. Aspek-aspek tersebut adalah memotivasi siswa, membimbing siswa merumuskan kesimpulan/ menemukan konsep, dan pengelolaan waktu.

Dengan penyempurnaan aspek-aspek di atas dalam penerapan metode pengajaran 
terarah diharapkan siswa dapat menyimpulkan apa yang telah mereka pelajari dan mengemukakan pendapatnya sehingga mereka akan lebih memahami tentang apa yang telah mereka lakukan.

Berikut disajikan hasil observasi aktivitas guru dan siswa.

Berdasarkan tabel di atas tampak bahwa aktivitas guru yang paling dominan pada siklus II adalah membimbing dan mengamati siswa dalam menemukan konsep yaitu $25 \%$. Jika dibandingkan dengan siklus I, aktivitas ini mengalami peningkatan. Aktivitas guru yang mengalami penurunan adalah memberi umpan balik/evaluasi/tanya jawab (16,6\%), menjelaskan materi yang sulit $(11,7)$. Meminta siwa mendiskusikan dan menyajikan hasil kegiatan $(8,2 \%)$, dan membimbing siswa merangkum pelajaran $(6,7 \%)$.
Sedangkan untuk aktivitas siswa yang paling dominan pada siklus II adalah Bekerja dengan sesama anggota kelompok yaitu (21\%). Jika dibandingkan dengan siklus I, aktivitas ini mengalami peningkatan. Aktivitas siswa yang mengalami penurunan adalah mendengarkan/ memperhatikan penjelasan guru (17,9\%). Diskusi antar siswa/antara siswa dengan guru $(13,8 \%)$, menulis yang relevan dengan $\mathrm{KBM}(7,7 \%)$ dan merangkum pembelajaran (6,7\%). Adapun aktivitas siswa yang mengalami peningkatan adalah membaca buku $(12,1 \%)$, menyajikan hasil pembelajaran $(4,6 \%)$, menanggapi/mengajukan pertanyaan/ide $(5,4 \%)$, dan mengerjakan tes evaluasi $(10,8 \%)$.

Berikutnya adalah rekapitulasi hasil tes formatif siswa terlihat pada tabel berikut.

Tabel 1. Rekapitulasi Hasil Tes Formatif Siswa Pada Siklus II

\begin{tabular}{clc}
\hline No & \multicolumn{1}{c}{ Uraian } & Hasil Siklus II \\
\hline 1 & Nilai rata-rata tes formatif & 75,31 \\
2 & Jumlah siswa yang tuntas belajar & 24 \\
3 & Persentase ketuntasan belajar & 75,00 \\
\hline
\end{tabular}

Dari tabel di atas diperoleh nilai ratarata prestasi belajar siswa adalah 75,31 dan ketuntasan belajar mencapai $75,00 \%$ atau ada 24 siswa dari 32 siswa sudah tuntas belajar. Hasil ini menunjukkan bahwa pada siklus II ini ketuntasan belajar secara klasikal telah mengalami peningkatan sedikit lebih baik dari siklus I. Adanya peningkatan hasil belajar siswa ini karena setelah guru menginformasikan bahwa setiap akhir pelajaran akan selalu diadakan tes sehingga pada pertemuan berikutnya siswa lebih termotivasi untuk belajar. Selain itu siswa juga sudah mulai mengerti apa yang dimaksudkan dan dinginkan guru dengan menerapkan metode belajar aktif model pengajaran terarah.

Dalam pelaksanaan kegiatan belajar diperoleh informasi dari hasil pengamatan sebagai berikut: (1) Memotivasi siswa. (2) Membimbing siswa merumuskan kesimpulan/menemukan konsep.

Pengelolaan waktu.

Pelaksanaan kegiatan belajar pada siklus II ini masih terdapat kekurangankekurangan. Maka perlu adanya revisi untuk dilaksanakan pada siklus II antara lain: (1) Guru dalam memotivasi siswa hendaknya dapat membuat siswa lebih termotivasi selama proses belajar mengajar berlangsung. (2) Guru harus lebih dekat dengan siswa sehingga tidak ada perasaan takut dalam diri siswa baik untuk mengemukakan pendapat atau bertanya. (3) Guru harus lebih sabar dalam membimbing siswa merumuskan kesimpulan/menemukan konsep. (4) Guru harus mendistribusikan waktu secara baik sehingga kegiatan pembelajaran dapat berjalan sesuai dengan yang diharapkan. (5) Guru sebaiknya menambah lebih banyak contoh soal dan memberi soal-soal latihan pada siswa untuk 
dikerjakan pada setiap kegiatan belajar mengajar.

\section{Siklus III}

Pada tahap ini peneliti mempersiapkan perangkat pembelajaran yang terdiri dari rencana pelajaran 3 , LKS 3 , soal tes formatif 3 dan alat-alat pengajaran yang mendukung. Pelaksanaan kegiatan belajar mengajar untuk siklus III dilaksanakan pada tanggal 25 Oktober 2018 di Kelas V dengan jumlah siswa 32 siswa. Dalam hal ini peneliti bertindak sebagai pengamat dengan dibantu oleh kepala sekolah SDN 04 Kalimas, sedangkan yang bertindak sebagai pengajar adalah. Adapun proses belajar mengajar mengacu pada rencana pelajaran dengan memperhatikan revisi pada siklus II, sehingga kesalahan atau kekurangan pada siklus II tidak terulang lagi pada siklus III.
Pengamatan dilaksanakan bersamaan dengan pelaksanaan belajar mengajar.

Pada akhir proses belajar mengajar siswa diberi tes formatif III dengan tujuan untuk mengetahui tingkat keberhasilan siswa dalam proses belajar mengajar yang telah dilakukan. Instrumen yang digunakan adalah tes formatif III. Adapun data hasil penelitian pada siklus III.

Dari aspek-aspek yang diamati pada kegiatan belajar mengajar (siklus III) yang dilaksanakan oleh guru dengan menerapkan metode pengajaran terarah mendapatkan penilaian cukup baik dari pengamat adalah memotivasi siswa, membimbing siswa merumuskan kesimpulan/menemukan konsep, dan pengelolaan waktu.

Penyempurnaan aspek-aspek diatas dalam menerapkan metode pengajaran terarah diharapkan dapat berhasil semaksimal mungkin.

Tabel 2. Pengelolaan Pembelajaran Pada Siklus III

\begin{tabular}{|c|c|c|c|c|}
\hline \multirow{2}{*}{ No } & \multirow{2}{*}{ Aspek yang diamati } & \multicolumn{2}{|c|}{ Penilaian } & \multirow{2}{*}{ Rata-rata } \\
\hline & & P1 & $\mathrm{P} 2$ & \\
\hline \multirow{14}{*}{ I } & Pengamatan KBM & & & \\
\hline & A. Pendahuluan & & & \\
\hline & 1. Memotivasi siswa & 3 & 3 & 3 \\
\hline & 2. Menyampaikan tujuan pembelajaran & 4 & 4 & 4 \\
\hline & B. Kegiatan Inti & & & \\
\hline & 1. Mendiskusikan langkah-langkah kegiatan & 4 & 4 & 4 \\
\hline & bersama siswa & 4 & 4 & 4 \\
\hline & 2. Membimbing siswa melakukan kegiatan & & & \\
\hline & $\begin{array}{l}\text { 3. Membimbing siswa mendiskusikan hasil } \\
\text { kegiatan dalam kelompok }\end{array}$ & 4 & 4 & 4 \\
\hline & $\begin{array}{l}\text { 4. Memberikan kesempatan pada siswa untuk } \\
\text { mempresentasikan hasil peneyelidikan }\end{array}$ & 4 & 3 & 3,5 \\
\hline & $\begin{array}{l}\text { 5. Membimbing siswa merumuskan } \\
\text { kesimpulan/menemukan konsep }\end{array}$ & 3 & 3 & 3 \\
\hline & C. Penutup & & & \\
\hline & 1. Membimbing siswa membuat rangkuman & 4 & 4 & 4 \\
\hline & 2. Memberikan evaluasi & 4 & 4 & 4 \\
\hline \multirow[t]{2}{*}{ II } & Pengelolaan Waktu & 3 & 3 & 3 \\
\hline & Antusiasme Kelas & & & \\
\hline \multirow[t]{2}{*}{ III } & 1. Siswa Antusias & 4 & 4 & 4 \\
\hline & 2. Guru Antusias & 4 & 4 & 4 \\
\hline & Jumlah & 45 & 44 & 44,5 \\
\hline
\end{tabular}


Tabel 3. Aktivitas Guru dan Siswa Pada Siklus III

\begin{tabular}{clc}
\hline No & \multicolumn{1}{c}{ Aktivitas Guru yang diamati } & Persentase \\
\hline 1 & Menyampaikan tujuan & 6,7 \\
2 & Memotivasi siswa/merumuskan masalah & 6,7 \\
3 & Mengkaitkan dengan pelajaran berikutnya & 10,7 \\
4 & Menyampaikan materi/langkah-langkah/strategi & 13,3 \\
5 & Menjelaskan materi yang sulit & 10,0 \\
6 & Membimbing dan mengamati siswa dalam menemukan & 22,6 \\
7 & konsep & 10,0 \\
8 & Meminta siswa menyajikan dan mendiskusikan hasil & 11,7 \\
9 & kegiatan & 10,0 \\
& Memberikan umpan balik & \\
& Membimbing siswa merangkum pelajaran & \\
\hline No & $\quad$ Aktivitas Siswa yang diamati & Persentase \\
\hline 1 & Mendengarkan/memperhatikan penjelasan guru & 20,8 \\
2 & Membaca buku siswa & 13,1 \\
3 & Bekerja dengan sesama anggota kelompok & 22,1 \\
4 & Diskusi antar siswa/antara siswa dengan guru & 15,0 \\
5 & Menyajikanhasil pembelajaran & 2,9 \\
6 & Mengajukan/menanggapi pertanyaan/ide & 4,2 \\
7 & Menulis yang relevan dengan KBM & 6,1 \\
8 & Merangkum pembelajaran & 7,3 \\
9 & Mengerjakan tes evaluasi/latihan & 8,5 \\
\hline
\end{tabular}

Berdasarkan tabel di atas tampak bahwa aktivitas guru yang paling dominan pada siklus III adalah membimbing dan mengamati siswa dalam menemukan konsep yaitu 22,6\%, sedangkan aktivitas menjelaskan materi yang sulit dan memberi umpan balik/evaluasi/tanya jawab menurun masing-masing sebesar (10\%) dan (11,7\%). Aktivitas lain yang mengalami peningkatan adalah mengaitkan dengan pelajaran sebelumnya (10\%), menyampaikan materi/strategi /langkah-langkah (13,3\%), meminta siswa menyajikan dan mendiskusikan hasil kegiatan (10\%), dan membimbing siswa merangkum pelajaran (10\%). Adapun aktivitas yang tidak mengalami perubaan adalah menyampaikan tujuan $(6,7 \%)$ dan memotivasi siswa $(6,7 \%)$.

Sedangkan untuk aktivitas siswa yang paling dominan pada siklus III adalah Bekerja dengan sesama anggota kelompok yaitu $(22,1 \%)$ dan menperhatikan penjelasan guru $(20,8 \%)$, aktivitas yang mengalami peningkatan adalah membaca buku siswa $(13,1 \%)$ dan diskusi antar siswa/antara siswa dengan guru $(15,0 \%)$. Sedangkah aktivitas yang lainnya mengalami penurunan.

Berikutnya adalah rekapitulasai hasil tes formatif siswa seperti terlihat pada tabel berikut.

Tabel 4. Rekapitulasi Hasil Tes Formatif Siswa Pada Siklus III

\begin{tabular}{clc}
\hline No & \multicolumn{1}{c}{ Uraian } & Hasil Siklus III \\
\hline 1 & Nilai rata-rata tes formatif & 80,31 \\
2 & Jumlah siswa yang tuntas belajar & 28 \\
3 & Persentase ketuntasan belajar & 87,50 \\
\hline
\end{tabular}


Berdasarkan tabel diatas diperoleh nilai rata-rata tes formatif sebesar 80,31 dan dari 32 siswa yang telah tuntas sebanyak 28 siswa dan 4 siswa belum mencapai ketuntasan belajar. Maka secara klasikal ketuntasan belajar yang telah tercapai sebesar $87,50 \%$ (termasuk kategori tuntas). Hasil pada siklus III ini mengalami peningkatan lebih baik dari siklus II. Adanya peningkatan hasil belajar pada siklus III ini dipengaruhi oleh adanya peningkatan kemampuan guru dalam menerapkan belajar aktif sehingga siswa menjadi lebih terbiasa dengan pembelajaran seperti ini sehingga siswa lebih mudah dalam memahami materi yang telah diberikan.

Pada tahap ini akan dikaji apa yang telah terlaksana dengan baik maupun yang masih kurang baik dalam proses belajar mengajar dengan penerapan belajar aktif. Dari data-data yang telah diperoleh dapat diuraikan sebagai berikut: (1) Selama proses belajar mengajar guru telah melaksanakan semua pembelajaran dengan baik. Meskipun ada beberapa aspek yang belum sempurna, tetapi persentase pelaksanaannya untuk masing-masing aspek cukup besar. (2) Berdasarkan data hasil pengamatan diketahui bahwa siswa aktif selama proses belajar berlangsung. (3) Kekurangan pada siklus-siklus sebelumnya sudah mengalami perbaikan dan peningkatan sehingga menjadi lebih baik. (4) Hasil belajar siswsa pada siklus III mencapai ketuntasan.

Pada siklus III guru telah menerapkan belajar aktif dengan baik dan dilihat dari aktivitas siswa serta hasil belajar siswa pelaksanaan proses belajar mengajar sudah berjalan dengan baik. Maka tidak diperlukan revisi terlalu banyak, tetapi yang perlu diperhatikan untuk tindakan selanjutnya adalah memaksimalkan dan mempertahankan apa yang telah ada dengan tujuan agar pada pelaksanaan proses belajar mengajar selanjutnya penerapan belajar aktif dapat meningkatkan proses belajar mengajar sehingga tujuan pembelajaran dapat tercapai.

\section{Pembahasan}

Melalui hasil penelitian ini menunjukkan bahwa metode belajar aktif model pengajaran terarah memiliki dampak positif dalam meningkatkan prestasi belajar siswa. Hal ini dapat dilihat dari semakin mantapnya pemahaman siswa terhadap materi yang disampaikan guru (ketuntasan belajar meningkat dari siklus I, II, dan III) yaitu masing-masing $65,63 \%, 75,00 \%$, dan $87,50 \%$. Pada siklus III ketuntasan belajar siswa secara klasikal telah tercapai.

Berdasarkan analisis data, diperoleh aktivitas siswa dalam proses belajar aktif dalam setiap siklus mengalami peningkatan. Hal ini berdampak positif terhadap prestasi belajar siswa yaitu dapat ditunjukkan dengan meningkatnya nilai rata-rata siswa pada setiap siklus yang terus mengalami peningkatan.

Berdasarkan analisis data, diperoleh aktivitas siswa dalam proses pembelajaran IPS pada pokok bahasan Makna peninggalan-peninggalan sejarah yang berskala nasional dan masa Hindu-Budha, dan Islam di Indonesia dengan metode belajar aktif model pengajaran terarah yang paling dominant adalah bekerja dengan menggunakan alat/media, mendengarkan/ memperhatikan penjelasan guru, dan diskusi antar siswa/antara siswa dengan guru. Jadi dapat dikatakan bahwa aktivitas isiwa dapat dikategorikan aktif.

Sedangkan untuk aktivitas guru selama pembelajaran telah melaksanakan langkahlangkah belajar aktif dengan baik. Hal ini terlihat dari aktivitas guru yang muncul di antaranya aktivitas membimbing dan mengamati siswa dalam mengerjakan kegiatan LKS/menemukan konsep, menjelaskan materi yang tidak dimengerti, 
memberi umpan balik/evaluasi/tanya jawab dimana prosentase untuk aktivitas di atas cukup besar.

\section{SIMPULAN DAN SARAN Simpulan}

Dari hasil kegiatan pembelajaran yang telah dilakukan selama tiga siklus, dan berdasarkan seluruh pembahasan serta analisis yang telah dilakukan dapat disimpulkan sebagai berikut: (1) Pembelajaran dengan metode belajar aktif model pengajaran terarah memiliki dampak positif dalam meningkatkan prestasi belajar siswa yang ditandai dengan peningkatan ketuntasan belajar siswa dalam setiap siklus, yaitu siklus I $(65,63 \%)$, siklus II $(75,00 \%)$, siklus III $(87,50 \%)$. (2) Penerapan metode belajar aktif model pengajaran terarah mempunyai pengaruh positif, yaitu dapat meningkatkan motivasi belajar siswa yang ditunjukan dengan rata-rata jawaban siswa yang menyatakan bahwa siswa tertarik dan berminat dengn metode belajar aktif model pengajaran terarah sehingga mereka menjadi termotivasi untuk belajar.

\section{Saran}

Dari hasil penelitian yang diperoleh dari uraian sebelumnya agar proses belajar mengajar IPS lebih efektif dan lebih memberikan hasil yang optimal bagi siswa, maka disampaikan saran sebagai berikut: (1) Untuk melaksanakan belajar aktif memerlukan persiapan yang cukup matang, sehingga guru harus mampu menentukan atau memilih topik yang benar-benar bisa diterapkan dengan metode belajar aktif model pengajaran terarah dalam proses belajar mengajar sehingga diperoleh hasil yang optimal. (2) Dalam rangka meningkatkan prestasi belajar siswa, guru hendaknya lebih sering melatih siswa dengan metode pembelajaran yang berbeda, walau dalam taraf yang sederhana, dimana siswa nantinya dapat menemukan pengetahuan baru, memperoleh konsep dan keterampilan, sehingga siswa berhasil atau mampu memecahkan masalah-masalah yang dihadapinya. (3) Perlu adanya penelitian yang lebih lanjut, karena hasil penelitian ini hanya dilakukan di SDN 04 Kalimas Tahun Pelajaran 2018/2019. (4) Untuk penelitian yang serupa hendaknya dilakukan perbaikan-perbaikan agar diperoleh hasil yang lebih baik.

\section{DAFTAR PUSTAKA}

Arikunto, Suharsimi. 1993. Manajemen Mengajar Secara Manusiawi. Jakarta: Rineksa Cipta.

Arikunto, Suharsimi. 2002. Dasar-dasar Evaluasi Pendidikan. Jakarta: Bumi Aksara.

Arikunto, Suharsimi. 2002. Prosedur Penelitian Suatu Pendekatan Praktek. Jakarta:Rineksa Cipta

Departemen Pendidikan dan Kebudayaan, 1994. Petunjuk Pelaksanaan Proses Belajar Mengajar, Jakarta. Balai Pustaka.

Djamarah, Syaiful Bahri. 2002. Strategi Belajar Mengajar. Jakarta: Rineksa Cipta.

Hadi, Sutrisno. 1981. Metodogi Research. Yayasan Penerbitan Fakultas Psikologi Universitas Gajah Mada. Yoyakarta.

Hamalik, Oemar. 1994. Metode Pendidikan. Bandung:Citra Aditya Bakti.

Hasibuan. J.J. dan Moerdjiono. 1998. Proses Belajar Mengajar. Bandung: Remaja Rosdakarya.

Hudoyo, H. 1990. Strategi Belajar Mengajar Matematika. Malang: IKIP Malang.

Kemmis, S. dan Mc. Taggart, R. 1988. The Action Research Planner. Victoria Dearcin University Press.

Margono. 1997. Metodologi Penelitian Pendidikan. Jakarta. Rineksa Cipta.

Mursell, James ( - ). Succesfull Teaching (terjemahan). Bandung: Jemmars. 
Ngalim, Purwanto M. 1990. Psikologi Pendidikan. Bandung: Remaja Rosdakarya.

Nur, Moh. 2001. Pemotivasian Siswa untuk Belajar. Surabaya. University Press. Universitas Negeri Surabaya.

Poerwodarminto. 1991. Kamus Umum Bahasa Indonesia. Jakarta: Bina Ilmu.

Rustiyah, N.K. 1991. Strategi Belajar Mengajar. Jakarta: Bina Aksara.

Sardiman, A.M. 1996. Interaksi dan Motivasi Belajar Mengajar. Jakarta: Bina Aksara.
Soekamto, Toeti. 1997. Teori Belajar dan Model Pembelajaran. Jakarta: PAUPPAI, Universitas Terbuka.

Sukidin, dkk. 2002. Manajemen Penelitian Tindakan Kelas. Insan Cendekia.

Suryosubroto, B. 1997. Proses Belajar Mengajar di Sekolah. Jakarta: Rineksa Cipta.

Usman, Moh. Uzer. 2001. Menjadi Guru Profesional. Bandung: Remaja Rosdakarya. 